\title{
Arbuscular mycorrhizal fungi to enhance the growth of tropical endangered species Pterocarpus indicus and Pericopsis mooniana in post gold mine field in Southeast Sulawesi, Indonesia
}

\author{
HUSNA", FAISAL DANU TUHETERU, ASRIANTI ARIF \\ Department of Forestry, Faculty of Forestry and Environmental Science, Universitas Halu Oleo. Jl. HEA Mokodompit, Kendari 93232, Southeast \\ Sulawesi, Indonesia. "email: husna@uho.ac.id
}

Manuscript received: 17 July 2021. Revision accepted: 24 August 2021.

\begin{abstract}
Husna, Tuheteru FD, Arif A. 2021. Arbuscular mycorrhizal fungi to enhance the growth of tropical endangered species Pterocarpus indicus and Pericopsis mooniana in post gold mine field in Southeast Sulawesi, Indonesia. Biodiversitas 22: $3844-3853$. Gold mining activities contribute to the national economy, but have a serious impact on forest and environmental degradation and pose a threat to tree species in the tropics. Reforestation of post-gold mining with tropical legume tree species is threatened with extinction. Arbuscular mycorrhizal fungi are effective in conservation of endangered plants and restoration of degraded land. The objective of the study was to evaluate the effect of native AM Fungi inoculation on the growth of Pterocarpus indicus and Pericopsis mooniana in nurseries and post-gold mining fields. P. indicus and P. mooniana seedlings were inoculated with Glomus claroideum Schenk \& Smith, Glomus coronatum Giovann., and mixed AMF (G. claroideum, G. coronatum). Uninoculated seedlings were used as control treatment, and they were maintained for 4 months under greenhouse conditions. After 4 months in greenhouse, seedlings were transferred to postgold mine and planted for 4 months. The percentage of AMF colonization, plant growth, nutrient content and uptake of N, P, K, Fe, Mn were measured after 4 months both in the greenhouse and the field. The percentage of AMF colonization under greenhouse conditions in $P$. indicus and P. mooniana ranged 5.67-75.3\% and 2.2-41.2\%. All AMF colonization tended to have higher shoot height, leaf numbers and nodules, plant dry weight and N, P, K content under greenhouse conditions. Shoot height, stem diameter, leaf dry weight, N, P, K, $\mathrm{Mn}$ and $\mathrm{Fe}$ under field conditions had higher inoculated seedlings than control four months after planting. AMF could be used to conserve endangered tree species in post-gold mining reforestation in the tropics.
\end{abstract}

Keywords: Arbuscular mycorrhizal fungus, gold mining land, Indonesia, restoration, tropical trees species

\section{INTRODUCTION}

Deforestation and forest degradation, especially due to mining and other extractive activities, have serious impacts on biodiversity loss, especially in terms of threats to tropical tree species. Therefore, post-mining land restoration is needed to restore the richness of plant species and the function of forest ecosystems. Ecological restoration and conservation are the central themes of global environmental policy (FAO-UNEP 2020). Global experiences show that projects to restore degraded land and forests have been successful or even failed (Thomas et al. 2014). Post-mining land has physical, chemical and biological characteristics that do not support vegetation growth and development (Sheoran et al. 2010). Therefore, designing an appropriate restoration mechanism is very important. To support the program and stimulate plant growth, it is necessary to provide seeds with beneficial soil microbes, namely the Arbuscular mycorrhizal fungi (Asmelash et al. 2016). Arbuscular mycorrhizal fungi (AMF) are obligate fungi in symbiosis with 70-90 terrestrial plant families (Smith and Read 2008; Tuheteru et al. 2019), including legumes and endangered species and aquatic plants (Tuheteru and $\mathrm{Wu} 2017$ ).

Adaptation and the success of seedlings in the field are vital components in restoration, reforestation and species conservation programs. Therefore, improving the quality of forestry plant seedlings by applying mycorrhizal fungi in the nursery is an important stage in ecosystem restoration activities (Urgiles et al. 2009). AMF increases the growth of various tropical tree species at the nursery scale (Turjaman et al. 2007; 2009; Wulandari et al. 2014; Husna et al. 2016; 2019a; 2021; Maulana et al. 2017; Prematuri et al. 2020). AMF has the potential to be developed for revegetation, reforestation and restoration and phytoremediation (Asmelash et al. 2016; Tuheteru et al. 2016; Husna et al. 2017; Wang et al. 2017; Dhalaria et al. 2020; Riaz et al. 2021). Several studies reported that the presence of AMF can accelerate plant growth in the land of various post-mining conditions in the world, including nickel mining (Husna et al. 2016; Amir et al. 2019), coal (Wulandari et al. 2016; Agus et al. 2018; Husna et al. 2019a), and gold (Husna et al. 2019b; 2021).

AMF is very important for the conservation programs of endangered plant species (Fuchs and Haselwandter 2008; Panwar and Tarafdar 2006; Zubek et al. 2009; Bothe et al. 2010; Husna et al. 2017; 2018). In Indonesia, the AMF application for the conservation of endangered species has been reported in species of Aquilaria malacensis and A. crasna (Turjaman et al. 2006a), A. filaria (Turjaman et al. 2006b) and Gonystylus bancanus (Muin 2003), Kalapia celebica (Husna et al. 2019b; 2021) 
and Pericopsis mooniana (Husna et al. 2016; 2019a). Postmining land restoration and tree species conservation with AMF application improve nutrient and water uptake, increase plant resistance to biotic and abiotic stresses, so that it can support plant growth and development on a greenhouse or field scale.

Pterocarpus indicus and P. mooniana are tropical tree species, belongs to Leguminosae. They produce luxury wood (Soerianegara and Lemmens 1994). Both species are classified as vulnerable by IUCN and trade-in of the species is restricted by listing in Appendix 2 of CITES now. They are potential species for reforestation and forest plantation programs (Gazal et al. 2004; Thomson 2006; Husna et al. 2018). P. indicus can be found in lowland evergreen primary and some secondary forests from near sea level to $1,300 \mathrm{~m}$ elevation, grows best in full sunshine and adapts to a wide range of soil types (Thomson 2006; Manipol et al. 2020). P. mooniana has distribution in lowland evergreen primary (200-350 m elevation) and grows in relatively infertile sandy regosol (Soerianegara and Lemmens 1994).

Previous studies showed that native AMF improves plant growth and plant nutrient uptake of $P$. mooniana on post-mining soils of serpentine and nickel (Husna et al. 2016; 2018), inceptisol (Husna et al. 2015a) and overburdened coal mining land (Husna et al. 2019a). However, the study on tailings media and gold post mining land is still limited. We strongly believe that inoculation of native AMF enhances plant growth and nutrient uptake of $P$. indicus and $P$. mooniana as two threatened tropical tree species. The purpose of this study was to examine the effects of native AMF inoculation on the growth and nutrient uptake of $P$. indicus and $P$. mooniana under greenhouse and gold post mining land.

\section{MATERIALS AND METHODS}

\section{Soil preparation}

Gold tailing soil was collected on 1-2 March 2019 from the disposal site of PT. Panca Logam Makmur, Bombana District, Southeast Sulawesi, Indonesia and stored in a greenhouse. Chemical and physical properties of gold tailing soil were analyzed at the Soil and Plant Laboratory of SEAMEO BIOTROP, Bogor, Indonesia (Table 1). Gold tailing soil mixed with ultisol soil and cow manure compost in a mixture ratio of 4:2:1 (v/v/v). Chemical characteristics of cow manure compost were as follows: $\mathrm{pH}$ $\left(\mathrm{H}_{2} \mathrm{O}\right)$ : 7.75 ; total $\mathrm{N}: 7.9 \mathrm{~g} \mathrm{~kg}^{-1}$; total $\mathrm{K}: 4.2 \mathrm{~g} \mathrm{~kg}^{-1}$ and total: $\mathrm{P}, 1.92 \mathrm{~g} \mathrm{~kg}^{-1}$.

\section{Arbuscular mycorrhizal fungal inoculum and inoculation}

The AMF inoculums used were Glomus claroideum Schenk \& Smith (B), Glomus coronatum Giovann. (C), and mixed AMF isolated from the rhizosphere of Pericopsis mooniana (Husna et al. 2015b). AMF inoculums were propagated in zeolite media and Pueraria javanica host for 3 months in the greenhouse of the Indonesian Mycorrhizas Association, Southeast Sulawesi Branch, Kendari. Polyethylene pots $(15 \times 20 \mathrm{~cm})$ were filled with $1000 \mathrm{~g}$ of sterilized gold tailing soil. AMF inoculation was obtained by placing ten grams $(10 \mathrm{~g})$ of inoculum of each species at $1-3 \mathrm{~cm}$ below the seedlings. Two new leaves of $P$. indicus and $P$. mooniana seedling were transplanted into the pots. The inoculated seedlings were maintained, watered, and observed for 4 months. Seedlings were watered daily with tap water to field capacity. Daily temperatures vary between 27 and $47^{\circ} \mathrm{C}$ with relative humidity of $45-79 \%$. Ten $g$ of sterilized zeolite were placed into no-inoculated pots as a control treatment.

Table 1. Physical and chemical properties of gold tailing and post gold mining soil

\begin{tabular}{|c|c|c|c|c|c|}
\hline \multirow{2}{*}{ Parameter } & \multirow{2}{*}{ Unit } & \multicolumn{2}{|c|}{ Gold tailing media } & \multicolumn{2}{|c|}{ Post gold mining land } \\
\hline & & Value & Criteria $^{a}$ & Value & Criteria $^{\mathrm{a}}$ \\
\hline $\mathrm{pH} \mathrm{H} \mathrm{H}_{2} \mathrm{O}$ & & 6.1 & low & 6.9 & Netral \\
\hline C-organic & $\%$ & 0.10 & Very low & 0.10 & Very low \\
\hline N Total & $\%$ & 0.05 & Very low & 0.07 & Very low \\
\hline $\mathrm{C} / \mathrm{N}$ ratio & & 2.1 & Very low & 1 & Very low \\
\hline $\mathrm{P}_{2} \mathrm{O}_{5}$ & $\mathrm{mg} / \mathrm{kg}$ & 11.5 & Medium & 25.5 & High \\
\hline $\mathrm{Ca}$ & $\mathrm{cmol} / \mathrm{kg}$ & 1.45 & Very low & 2.13 & Low \\
\hline $\mathrm{Mg}$ & $\mathrm{cmol} / \mathrm{kg}$ & 0.73 & Low & 0.35 & Low \\
\hline $\mathrm{Na}$ & $\mathrm{cmol} / \mathrm{kg}$ & 0.13 & Low & 0.33 & Low \\
\hline $\mathrm{K}$ & $\mathrm{cmol} / \mathrm{kg}$ & 0.09 & Very low & 0.38 & Low \\
\hline CEC & $\mathrm{cmol} / \mathrm{kg}$ & 4.77 & Very low & 27.30 & High \\
\hline Base saturation & $\%$ & 50.36 & Medium & 11.68 & Very low \\
\hline $\mathrm{Al}^{3+} \mathrm{Hdd}$ & $\mathrm{me} / 100 \mathrm{~g}$ & 0.10 & Very low & 0.11 & Very low \\
\hline \multicolumn{6}{|l|}{ Texture } \\
\hline Sand & $\%$ & 79.2 & Loamy Sand & 42.2 & Clay Loam \\
\hline Silt & $\%$ & 16.2 & & 29.5 & \\
\hline Clay & $\%$ & 4.6 & & 28.3 & \\
\hline Mn Total & $\mathrm{mg} / \mathrm{kg}$ & 487 & Very high & 939.8 & Very high \\
\hline $\mathrm{Fe} 2 \mathrm{O} 3$ & $\%$ & 0.73 & Very high & 4.61 & Very high \\
\hline Cd Total & $\mathrm{mg} / \mathrm{kg}$ & 0.6 & Normal & 0.51 & Normal \\
\hline $\mathrm{Pb}$ Total & $\mathrm{mg} / \mathrm{kg}$ & 9.8 & Normal & 16.3 & Normal \\
\hline $\mathrm{Hg}$ & $\mathrm{mg} / \mathrm{kg}$ & $<0.00004$ & Normal & - & \\
\hline
\end{tabular}




\section{Seedling preparation}

$P$. indicus and $P$. mooniana fruits were collected from trees growing on the Halu Oleo University Campus in Kendari, Southeast Sulawesi. These fruits are orthodox. The seeds are soaked in hot water with an initial temperature of $50^{\circ} \mathrm{C}$ until cold for 24 hours and then germinated in plastic sprouts at the Plastic House of the Indonesian Mycorrhizal Association (IMA), Southeast

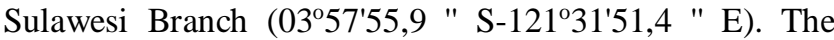
study was conducted from March to July 2019. The experiment consisted of four treatments of $P$. indicus and $P$. mooniana seedlings: (i) control (without inoculum), (ii) inoculated with Glomus claroideum Schenk \& Smith, (iii) inoculated with Glomus coronatum Giovann., and (iv) inoculated with mixed AMF ( $G$. claroideum, $G$. coronatum). Each treatment has 15 replications.

\section{Transplanting in the field}

The study site is located in the gold post-mining of PT. Panca Logam Makmur, Bombana, Southeast Sulawesi $\left(04^{\circ} 39^{\prime} 24,6^{\prime \prime} \mathrm{S}-121^{\circ} 533^{\prime} 58.1^{\prime \prime} \mathrm{E}\right)$. The study site was cleared 3 months before the start of the study and had no vegetation. The Bombana region has a tropical climate with average annual rainfall varying from $1083 \mathrm{~mm}$ to $1325 \mathrm{~mm}$ and is located at $101 \mathrm{~m}$ elevation. The recapitulation of the average temperature in the morning is $37.43^{\circ} \mathrm{C}$, in the afternoon is $37.43^{\circ} \mathrm{C}$ and in the late afternoon is $32.59^{\circ} \mathrm{C}$. The average humidity in the morning is $38.32 \%, 38.24 \%$ in the afternoon and $45.47 \%$ in the late afternoon. In this study, the number of rain occurrences was 49 days.

The field experiment was designed by using a Randomized Block Design with four treatments with three blocks. Each block has four treatments, namely (1) control (non AMF inoculation), (2) Glomus claroideum inoculation, (3) Glomus coronatum inoculation., and (4) mixed AMF ( $G$. claroideum, $G$. coronatum) inoculation. Planting was carried out at $2 \times 2 \mathrm{~m}$ spacing with planting hole of $40 \times 40 \times 40 \mathrm{~cm}$. Seedlings of $P$. indicus and $P$. mooniana aged 11 months were transferred and planted in holes according to treatment. Four $\mathrm{kg}$ of cow manure compost was applied to each planting hole in each treatment. Chemical fertilizer $\left(\mathrm{N}: \mathrm{P}_{2} \mathrm{O}_{5}: \mathrm{K}_{2} \mathrm{O} / 16: 16: 16\right)$ was applied as much as $50 \mathrm{~g}$ per plant one day after planting. Maintenance was done by watering with tap water every two days and weeding. Temperature and humidity measurements were carried out every day.

\section{Growth parameter}

Parameters observed in this study include: Plant height and diameter were measured on the stem at a height of 1 $\mathrm{cm}$ above the soil medium at greenhouse condition and 3 $\mathrm{cm}$ above the soil at field condition. The number of leaves and nodules. They were counted at the end of the study. Shoots and roots were separately harvested and oven-dried at $70^{\circ} \mathrm{C}$ for 48 hours and then weighed. Dried weight of 10 leaves per plant from the field. They were randomly selected. Phosphorus $(P)$ concentration of the plant was analyzed using SL-MU-TT-05 (Bray I/II) method, while nitrogen $(\mathrm{N})$ concentration of the plant was analyzed using SN 13-4721-1998 (Kjeldahl) method. K, Mn and Fe concentrations were analyzed using $\mathrm{HNO}_{3}-\mathrm{HClO}_{4}$ method (Carter 1993). The $N, P, K, M n$, and Fe content were calculated by multiplying the nutrients content of the plant by the plant dry weight. The increase/decrease of nutrients content of plant inoculated with mycorrhiza relative to control plants was calculated based on following formula $=$ [nutrient content of mycorrhizal plant - nutrient content of non-mycorrhizal plant/nutrient absorption of nonmycorrhizal plant] x 100\% (Wang et al. 2005).

Seed quality index (SQI) was calculated using formula as follows (Duryea and Brown 1984):

Seed Quality Index $($ SQI $)=[$ Shoot dry weight + root dry weight $] /[$ (height/diameter) + (dry weight of shoot/root dry weight)]. Seedlings have high quality if the value of $\mathrm{SQI} \geq 0.09$.

\section{Determination of mycorrhizal colonization and Mycorrhizae Inoculation Effect (MIE)}

The $P$. indicus and $P$. mooniana roots were rinsed under running water. The roots were then soaked in $10 \% \mathrm{KOH}$ for 24 hours, followed by acidifying in $2 \% \mathrm{HCl}$ for 30 minutes, and finally stained with trypan blue. The number of AMF colonies were calculated using formula by Brundrett et al. (1996):

$[\Sigma$ number of fields of view colonized $/ \Sigma$ total observed field of view] x $100 \%$.

Mycorrhizae Inoculation Effect (MIE) was calculated using formula by Habte and Manjunath (1991):

[total dry weight of mycorrhizal plant-total dry weight of non-mycorrhizal plant/total dry weight of mycorrhizal plant] x $100 \%$.

\section{Statistical analysis}

Each unit of observation was analyzed by analysis of variance (ANOVA). Differences between treatments were analyzed using LSD at the $95 \%$ confidence level.

\section{RESULTS AND DISCUSSION}

\section{Mycorrhizal colonization and plant growth in the greenhouse}

Arbuscular mycorrhizal fungi colonized all seedlings of $P$. indicus and $P$. mooniana (Table 2). $P$. indicus seedlings inoculated with $G$. coronatum and mixed AMF had higher AM colonization than control. Shoot height, and the number of nodule of $P$. indicus colonized by AM fungi was higher than those of control seedling (Table 2). Stem diameter of $P$. indicus inoculated with AMF was not significantly different compared to control. AMF inoculation on $P$. mooniana with $G$. claroideum, $G$. coronatum and mixed AMF increased shoot height and stem diameter of $P$. mooniana significantly $(p<0.05)$, however, shoot height of three types of AMF treatments were not significantly different $(\mathrm{p}>0.05)$. The number of leaves and nodule of $P$. mooniana colonized by $G$. 
coronatum was higher than the other treatments. There was no difference in number of leaves and nodule between seedlings colonized by mixed AMF and control seedlings.

Inoculation of AMF increased the initial growth of two endangered trees species $P$. indicus and $P$. mooniana after four months of transplanting under greenhouse conditions (Table 2). The results of this study indicated that AMF inoculation in the greenhouse or nursery is very important to support the success of planting. The results of this study confirmed the results of the study conducted by Urgiles et al. (2009) who stated that colonization of native AMF colonization enhanced the growth of $C$. montana and $H$. americanus in the nursery condition. Previous studies showed that native AMF increased the growth of $P$. mooniana in greenhouse and nursery scale on inceptisol media (Husna et al. 2015), serpentine (Husna et al. 2016) and coal spoil (Husna et al. 2019). In gold tailings media, native $\mathrm{AMF}$ is effective in increasing the growth of $K$. celebica (Husna et al. 2019; 2021), N. orientalis (Tuheteru et al. 2020), Paspalum (Fiqri et al. 2016), E. cladacalyx (Madejon et al. 2012), and D. viscosa, A, eucomus and $I$. cylindrica (Orłowska et al. 2011). Inoculation of 2 g AMF improved the growth of Pongamia pinnata plants in open pit coal mine soil media (Agus et al. 2018). Inoculation of
AMF (G. decipiens and G. clarum) increased early growth and nutrient uptake of Mallotus paniculatus and Albizia under nursery conditions (Wulandari et al. 2014).

$P$. indicus colonized by $G$. claroideum and mixed AMF had higher dry weight than control and $G$. coronatum inoculation treatment (Table 3). AMF inoculation by $G$. claroideum, G. coronatum and mixed AMF increased shoot dry weight and total dry weight of $P$. indicus significantly. Shoot dry weight and total dry weight of $P$. indicus seedlings inoculated by $G$. claroideum, G. coronatum and mixed AMF were not significantly different. G. coronatum inoculation on $P$. indicus did not increase total dry weight (Table 3). AMF inoculation by $G$. claroideum, $G$. coronatum and mixed AMF increased shoot, root and total dry weight of $P$. mooniana. Shoot, root and total dry weight of $P$. mooniiana seedlings in the three AMF inoculation treatments were not significantly different. The MIE of $P$. indicus and $P$. mooniana values ranged from 37,5 to $50.6 \%$ and 61,5 to $63,2 \%$ (Table 3 ). Shoot and roots ratio of $P$. indicus and $P$. mooniana was not different among the seedlings (Table 3 ). There was no significant effect on SQI of $P$. indicus between the non-inoculated and inoculated plants. AMF inoculation by G. claroideum, $G$. coronatum, and mixed AMF improve SQI of P. mooniana.

Table 2. The effect of four months AMF inoculation on mycorrhizal colonization, shoot height, stem diameter, leaf and nodule of $P$. indicus and $P$. mooniana in the greenhouse conditions

\begin{tabular}{llclll}
\hline \multicolumn{1}{c}{$\begin{array}{c}\text { Plant species } \\
\text { treatment }\end{array}$} & \multicolumn{1}{c}{$\begin{array}{c}\text { Mycorrhizal } \\
\text { colonization }(\mathbf{\%}) *\end{array}$} & $\begin{array}{c}\text { Shoot height } \\
(\mathbf{c m}) *\end{array}$ & $\begin{array}{c}\text { Stem Diameter } \\
(\mathbf{m m}) *\end{array}$ & Leaf number* & Nodule* \\
\hline$P$. indicus & & & & & \\
Control & $5.67 \pm 1.113 \mathrm{c}$ & $17.80 \pm 0.723 \mathrm{c}$ & $3.88 \pm 0.444 \mathrm{a}$ & $22.67 \pm 4.645 \mathrm{~b}$ & $7.00 \pm 1.155 \mathrm{~d}$ \\
G. claroideum & $52.7 \pm 19.047 \mathrm{~b}$ & $42.50 \pm 0.759 \mathrm{a}$ & $3.79 \pm 0.204 \mathrm{a}$ & $61.00 \pm 11.00 \mathrm{a}$ & $16.67 \pm 1.443 \mathrm{c}$ \\
G. coronatum & $69.9 \pm 19.047 \mathrm{ab}$ & $37.47 \pm 1.223 \mathrm{~b}$ & $3.85 \pm 0.195 \mathrm{a}$ & $51.33 \pm 15.61 \mathrm{ab}$ & $50.33 \pm 0.881 \mathrm{a}$ \\
Mixed AMF & $75.3 \pm 3.1535 \mathrm{a}$ & $39.63 \pm 1.954 \mathrm{ab}$ & $4.34 \pm 0.316 \mathrm{a}$ & $72.33 \pm 8.114 \mathrm{a}$ & $34.67 \pm 1.5 \mathrm{~b}$ \\
$P$. mooniana & & & & \\
Control & $2.2 \pm 0.502 \mathrm{c}$ & $15.63 \pm 0.726 \mathrm{~b}$ & $3.23 \pm 0.117 \mathrm{c}$ & $6.00 \pm 0.577 \mathrm{c}$ & $3.67 \pm 1.667 \mathrm{c}$ \\
G. claroideum & $39.6 \pm 0.580 \mathrm{ab}$ & $21.73 \pm 0.384 \mathrm{a}$ & $4.34 \pm 0.072 \mathrm{a}$ & $15.00 \pm 0.577 \mathrm{~b}$ & $30.00 \pm 6.244 \mathrm{~b}$ \\
G. coronatum & $36.5 \pm 2.214 \mathrm{~b}$ & $21.23 \pm 0.545 \mathrm{a}$ & $3.82 \pm 0.200 \mathrm{~b}$ & $14.00 \pm 0.577 \mathrm{a}$ & $64.33 \pm 5.783 \mathrm{a}$ \\
Mixed AMF & $41.2 \pm 0.536 \mathrm{a}$ & $21.90 \pm 0.550 \mathrm{a}$ & $3.86 \pm 0.165 \mathrm{~b}$ & $16.00 \pm 0.577 \mathrm{bc}$ & $16.67 \pm 4.409 \mathrm{bc}$ \\
\hline
\end{tabular}

Note: Average values followed by different letters in the same column are significantly different at LSD (P<0.05); *Mean \pm SE

Table 3. Total dry weight, shoot and root dry weight, and SQI of non-AMF and four months AMF inoculated of $P$. indicus and $P$. mooniana in the greenhouse

\begin{tabular}{|c|c|c|c|c|c|c|}
\hline \multirow{2}{*}{$\begin{array}{l}\text { Plant species } \\
\text { treatment }\end{array}$} & \multicolumn{3}{|c|}{ Dry weight (g/plant)* } & \multirow[t]{2}{*}{ MIE (\%)* } & \multirow{2}{*}{$\begin{array}{c}\text { Ratio of shoot } \\
\text { and root * }\end{array}$} & \multirow{2}{*}{ SQI* } \\
\hline & Roots & Shoots & Total & & & \\
\hline \multicolumn{7}{|l|}{ P. indicus } \\
\hline Control & $0.46 \pm 0.02 c$ & $1.65 \pm 0.141 b$ & $2.10 \pm 0.323 b$ & - & $3.63 \pm 0.174 a$ & $0.489 \pm 0.041 \mathrm{a}$ \\
\hline G. claroideum & $0.91 \pm 0.057 \mathrm{ab}$ & $3.32 \pm 0.360 \mathrm{a}$ & $4.22 \pm 0.420 \mathrm{a}$ & $50.6 \pm 8.830$ & $3.6 \pm 0.302 \mathrm{a}$ & $0.283 \pm 0.013 a$ \\
\hline G. coronatum & $0.76 \pm 0.111 b$ & $2.72 \pm 0.191 \mathrm{a}$ & $3.47 \pm 0.781 \mathrm{ab}$ & $50.1 \pm 8.830$ & $3.87 \pm 0.774 a$ & $0.267 \pm 0.071 \mathrm{a}$ \\
\hline Mixed AMF & $1.07 \pm 0.129 a$ & $3.29 \pm 0.264 a$ & $4.37 \pm 0.394 a$ & $37.5 \pm 10.527$ & $3.10 \pm 0.115 \mathrm{a}$ & $0.357 \pm 0.038 \mathrm{a}$ \\
\hline \multicolumn{7}{|l|}{ P. mooniana } \\
\hline Control & $0.65 \pm 0.065 b$ & $2.40 \pm 0.162 b$ & $3.05 \pm 0.220 b$ & - & $3.72 \pm 0.205 \mathrm{a}$ & $2.40 \pm 0.285 b$ \\
\hline G. claroideum & $1.39 \pm 0.157 \mathrm{a}$ & $6.96 \pm 0.379 a$ & $8.36 \pm 0.285 a$ & $63,2 \pm 3.910$ & $5.20 \pm 0.907 a$ & $8.73 \pm 1.673 a$ \\
\hline G. coronatum & $1.71 \pm 0.135 \mathrm{a}$ & $6.60 \pm 0.371 \mathrm{a}$ & $8.31 \pm 0.441 \mathrm{a}$ & $62,9 \pm 4.024$ & $3.90 \pm 0.327 \mathrm{a}$ & $5.83 \pm 0.424 a$ \\
\hline Mixed AMF & $1.55 \pm 0.079 a$ & $6.42 \pm 0.591 \mathrm{a}$ & $7.97 \pm 0.591 \mathrm{a}$ & $61,5 \pm 2.184$ & $4.17 \pm 0.462 \mathrm{a}$ & $5.96 \pm 1.018 \mathrm{a}$ \\
\hline
\end{tabular}

Note: Average values followed by different letters in the same column are significantly different at LSD $(\mathrm{P}<0.05) ;{ }^{*} \mathrm{Mean} \pm \mathrm{SE}$ 
Table 4. N, P, K, Mn and Fe concentration in the root of non-AMF inoculated and four months of AMF inoculation in Pterocarpus indicus and Pericopsis mooniana grown in the greenhouse

\begin{tabular}{|c|c|c|c|c|c|}
\hline \multirow{2}{*}{ Plant species treatment } & \multicolumn{5}{|c|}{ Concentration $\left(\mathrm{mg} \mathrm{g}^{-1}\right) *$} \\
\hline & $\mathbf{N}$ & $\mathbf{P}$ & $\mathbf{K}$ & Mn & $\mathbf{F e}$ \\
\hline \multicolumn{6}{|l|}{ P. indicus } \\
\hline Control & $20.2 \pm 0.75$ & $3.1 \pm 0.22$ & $20.8 \pm 2.53$ & $0.69 \pm 0.017 \mathrm{a}$ & $0.19 \pm 0.052$ \\
\hline G. claroideum & $20.6 \pm 1.07$ & $3.1 \pm 0.08$ & $18.2 \pm 0.71$ & $0.70 \pm 0.010 \mathrm{a}$ & $0.16 \pm 0.053$ \\
\hline G. coronatum & $23.5 \pm 1.06$ & $2.8 \pm 0.08$ & $20.9 \pm 0.71$ & $0.41 \pm 0.010 \mathrm{~b}$ & $0.16 \pm 0.052$ \\
\hline Mixed AMF & $20.4 \pm 0.08$ & $3.5 \pm 0.08$ & $19.6 \pm 2.22$ & $0.23 \pm 0.022 b$ & $0.17 \pm 0.002$ \\
\hline \multicolumn{6}{|l|}{ P. mooniana } \\
\hline Control & $17.3 \pm 1.12$ & $4.0 \pm 0.37$ & $17.8 \pm 1.33$ & $0.23 \pm 81.388$ & $1.57 \pm 0.294$ \\
\hline G. claroideum & $15.3 \pm 1.06$ & $2.7 \pm 0.16$ & $15.4 \pm 1.70$ & $0.19 \pm 37.239$ & $1.02 \pm 0.049$ \\
\hline G. coronatum & $17.0 \pm 1.53$ & $4.4 \pm 0.73$ & $13.8 \pm 2.58$ & $0.30 \pm 73.053$ & $1,23 \pm 0.202$ \\
\hline Mixed AMF & $17.6 \pm 1.25$ & $4.5 \pm 0.49$ & $14.2 \pm 1.67$ & $0.19 \pm 20.207$ & $0.87 \pm 0.083$ \\
\hline
\end{tabular}

Note: Average values followed by different letters in the same column are significantly different at LSD $(\mathrm{P}<0.05) ; *$ Mean \pm SE

Table 5. N, P, K, Mn and Fe contents in the root of non-AMF inoculated and four months of AMF inoculation in Pterocarpus indicus and Pericopsis mooniana in the greenhouse

\begin{tabular}{lccccc}
\hline \multirow{2}{*}{ Plant species treatment } & \multicolumn{3}{c}{${\text { Content }\left(\mathbf{m g ~ p l a n t}^{-1}\right)}^{*}$} \\
\cline { 2 - 6 } & $\mathbf{N}$ & $\mathbf{P}$ & $\mathbf{K}$ & $\mathbf{M n}$ & Fe \\
\hline $\boldsymbol{P}$. indicus & & & & \\
$\quad$ Control & $9.29 \pm 0.58 \mathrm{~b}$ & $1.43 \pm 0.11 \mathrm{c}$ & $9,57 \pm 1.45 \mathrm{~b}$ & $0.32 \pm 0.006 \mathrm{~b}$ & $0.09 \pm 0.019 \mathrm{~b}$ \\
$\quad$ G. claroideum & $18.7 \pm 1.94 \mathrm{a}$ & $2.82 \pm 0.27 \mathrm{ab}$ & $16,56 \pm 2.16 \mathrm{ba}$ & $0.64 \pm 0.016 \mathrm{a}$ & $0.15 \pm 0.082 \mathrm{ab}$ \\
$\quad$ G. coronatum & $17.8 \pm 1.94 \mathrm{a}$ & $2.13 \pm 0.26 \mathrm{bc}$ & $15,88 \pm 2.16 \mathrm{ba}$ & $0.31 \pm 0.016 \mathrm{~b}$ & $0.12 \pm 0.082 \mathrm{~b}$ \\
$\quad$ Mixed AMF & $21.8 \pm 2.54 \mathrm{a}$ & $3.75 \pm 0.37 \mathrm{a}$ & $20,97 \pm 1.669 \mathrm{a}$ & $0.25 \pm 0.014 \mathrm{~b}$ & $0.18 \pm 0.031 \mathrm{a}$ \\
$\boldsymbol{P}$. mooniana & & & & & \\
$\quad$ Control & $11.25 \pm 1.92 \mathrm{c}$ & $2.60 \pm 1.03 \mathrm{~b}$ & $11.57 \pm 0.80$ & $0.38 \pm 0.072$ & $1.02 \pm 0.295$ \\
$\quad$ G. claroideum & $21.27 \pm 2.14 \mathrm{~b}$ & $3.75 \pm 7.24 \mathrm{a}$ & $21.41 \pm 3.79$ & $0.10 \pm 0.067$ & $1.42 \pm 0.013$ \\
$\quad$ G. coronatum & $29.07 \pm 0.90 \mathrm{a}$ & $7.52 \pm 7.20 \mathrm{a}$ & $23.60 \pm 4.87$ & $0.13 \pm 0.112$ & $2.10 \pm 0.049$ \\
$\quad$ Mixed AMF & $27.28 \pm 3.01 \mathrm{ab}$ & $6.98 \pm 5.78 \mathrm{ab}$ & $22.01 \pm 3.53$ & $0.08 \pm 0.001$ & $1.35 \pm 0.066$ \\
\hline
\end{tabular}

Note: Average values followed by different letters in the same column are significantly different at LSD $(\mathrm{P}<0.05) ; *$ Mean \pm SE

Mycorrhizal Inoculation Effect (MIE) in P. indicus was 50.6, 50.1 and 37.5 when inoculated with G. clarodeum, $G$. coronatum and mixed AMF, respectively; while MIE in $P$. mooniana was $63.2,62.9$ and 61.5 , respectively. $P$. mooniana was more dependent on AMF colonization than P. indicus. Plant species that are highly dependent on AMF colonization have an MIE of 50-75\% (Habte and Manjunath 1991). A high MIE value indicates that the growth and survival $P$. mooniana depend on the presence of symbiosis with AMF. This research is in line with research on $P$. mooniana plants in various soil media, including inceptisol (Husna et al. 2015), ultramafic (Husna et al. 2016) and coal spoil (Husna et al. 2019). A high dependency on AMF has also been reported for other endangered tree species, i.e., Aquilaria malacensis and $A$. crasna (Turjaman et al. 2006a) and K. celebica (Husna et al. 2021). The differences in MIE of tree species are closely related to the characteristics of the roots and root hairs (Habte and Manjunath 1991). P. mooniana has a high mycorrhizal dependence presumably due to its low branching and poor root hairs.

\section{Nutrient content of shoot and root in plant grown in the green house}

The N, P, K and Fe concentrations in the root of $P$. indicus dan P. mooniana among the inoculated seedlings were not significantly different (Table 4). The concentration of $\mathrm{Mn}$ in the root of $P$. indicus colonized by G. coronatum and mixed AMF was lower than control and G. claroideum inoculation (Table 4). The $\mathrm{Mn}$ concentration of $P$. mooniana root did not differ among seedlings.

AMF inoculation by G. claroideum, G. coronatum dan mixed AMF increased the $\mathrm{N}$ and $\mathrm{K}$ content in the shoot of $P$. indicus, although there was no difference between the AMF inoculation treatments in $P$. indicus seedlings. $P$. indicus colonized by G. claroideum dan mixed AMF had higher $\mathrm{P}$ and $\mathrm{Fe}$ content in the root than control and $G$. coronatum inoculation (Table 5). P. indicus colonized by G. claroideum had higher $\mathrm{Mn}$ content in the root than control, G. claroideum and mixed AMF (Table 5). AMF inoculation by $G$. coronatum and mixed AMF increased the $\mathrm{N}$ content of $P$. mooniana roots. There was no difference in root $\mathrm{P}$ content between seedlings colonized by mixed AMF and control treatment. The $\mathrm{K}, \mathrm{Mn}$, and $\mathrm{F}$ content in the root of $P$. mooniana did not differ among the seedlings.

Concentration of $\mathrm{K}$ and $\mathrm{Mn}$ in inoculated seedlings of $P$. indicus shoots was not significantly different (Table 6). The concentration of $\mathrm{N}$ in the shoot of $P$. indicus colonized by $G$. coronatum and control was higher than in the mixed AMF and G. claroideum inoculation (Table 6). Inoculation 
of the mixed AMF increased the shoot $\mathrm{P}$ and $\mathrm{Fe}$ concentration of $P$. indicus. There was no difference in shoot $\mathrm{N}, \mathrm{P}, \mathrm{K}, \mathrm{Mn}$ and $\mathrm{Fe}$ concentration of $P$. mooniana among the inoculated seedlings (Table 6).

AMF inoculation by $G$. claroideum, $G$. coronatum dan mixed AMF increased the $\mathrm{N}, \mathrm{K}$ and $\mathrm{Mn}$ content in the shoots of $P$. indicus. There was no significant difference between $\mathrm{K}$ content in the soot of $P$. indicus seedlings inoculated by $G$. claroideum, G. coronatum and control. P. indicus inoculated by mixed AMF had higher shoot $\mathrm{P}$ and Fe content than control and $G$. coronatum inoculation (Table 7). AMF inoculation by $G$. claroideum, $G$. coronatum, and mixed AMF increased shoot N, P, K and Mn content of $P$. mooniana. Shoot Fe content of $P$. mooniana did not differ among the seedlings.

\section{The effect of AMF inoculation on changes in nutrient content}

AMF inoculation increased the $\mathrm{N}, \mathrm{P}, \mathrm{K}, \mathrm{Mn}$ content in the root as well as N, P, K, Mn and Fe contents in the shoot of $P$. indicus seedlings. The mixed AMF treatment decreased $\mathrm{Fe}$ content in the root by $55,3 \%$ (Table 8). $P$. mooniana inoculated by G. claroideum, G. coronatum and mixed AMF had higher N, P, K, Mn and Fe content in the root and $\mathrm{N}, \mathrm{P}, \mathrm{K}$ and $\mathrm{Fe}$ in the shoot. The mixed AMF treatment decreased $\mathrm{Mn}$ content in the shoot by $11,3 \%$ (Table 8).

The results of our study confirmed the positive effect of AMF inoculation on plant growth, nutrient uptake of $P$. indicus and $P$. mooniana grew in gold post-mine land. The results of this study indicate that local AMF is effective in increasing plant growth both in greenhouses and in the field. Corresponding to our results, that AMF inoculation of $G$. macrocarpum and $G$. fasciculatum significantly increased the survival rate and growth of Cassia siamea in Indian wasteland in field one year after transplanting (Giri et al. 2005). A previous study by Wulandari et al. (2016) showed that inoculation of the three native AMF increased the survival rate, plant growth and uptake of N, P of Albizia saman and Paraserianthes falcataria in post-opencast coal mine field (Wulandari et al. 2016). Local AMF was effective in increasing the growth of Pericopsis mooniana at 24 and 36 months after planting in nickel post mining land (Husna et al. 2017, 2018). The positive effect of AMF was shown on the growth of Metrosideros laurifolia in ultramafic soil in New Caledonia (Amir et al. 2019).

Table 6. The N, P, K, Mn and Fe concentration in the shoot of non-AMF inoculated and four months of AMF inoculation in $P$. indicus and P. mooniana in the greenhouse

\begin{tabular}{|c|c|c|c|c|c|}
\hline \multirow{2}{*}{ Plant species treatment } & \multicolumn{5}{|c|}{ Concentration $\left(\mathrm{mg} \mathrm{g}^{-1}\right)^{*}$} \\
\hline & $\mathbf{N}$ & $\mathbf{P}$ & $\mathbf{K}$ & Mn & $\mathbf{F e}$ \\
\hline \multicolumn{6}{|l|}{ P. indicus } \\
\hline Control & $26.1 \pm 1.04 \mathrm{a}$ & $3.3 \pm 0.11 b$ & $29.0 \pm 0.91$ & $0.128 \pm 0.014$ & $0.221 \pm 0.046 b$ \\
\hline G. claroideum & $22.9 \pm 0.41 b$ & $2.4 \pm 0.11 \mathrm{c}$ & $24.8 \pm 3.71$ & $0.155 \pm 0.017$ & $0.161 \pm 0.012 b$ \\
\hline G. coronatum & $24.9 \pm 0.21 \mathrm{a}$ & $2.4 \pm 0.08 \mathrm{c}$ & $22.6 \pm 2.31$ & $0.169 \pm 0.016$ & $0.189 \pm 0.021 b$ \\
\hline Mixed AMF & $21.9 \pm 0.39 b$ & $3.8 \pm 0.09 \mathrm{a}$ & $26.7 \pm 2.31$ & $0.184 \pm 0.003$ & $0.635 \pm 0.069 a$ \\
\hline \multicolumn{6}{|l|}{ P. mooniana } \\
\hline Control & $21.8 \pm 0.95$ & $3.7 \pm 0.08$ & $29.3 \pm 2.29$ & $0.168 \pm 0.041$ & $0.154 \pm 0.010$ \\
\hline G. claroideum & $25.5 \pm 1.85$ & $3.5 \pm 0.42$ & $30.2 \pm 2.86$ & $0.131 \pm 0.005$ & $0.136 \pm 0.019$ \\
\hline G. coronatum & $25.9 \pm 2.99$ & $3.9 \pm 0.46$ & $27.6 \pm 0.89$ & $0.131 \pm 0.018$ & $0.154 \pm 0.056$ \\
\hline Mixed AMF & $23.5 \pm 2.46$ & $3.9 \pm 0.24$ & $23.0 \pm 4.16$ & $0.149 \pm 0.012$ & $0.585 \pm 4.568$ \\
\hline
\end{tabular}

Note: Average values followed by different letters in the same column are significantly different at LSD $(\mathrm{P}<0.05) ; *$ Mean \pm SE

Table 7. Shoot N, P, K, Mn and Fe contents of non-AMF inoculated and four months of AMF inoculation in Pterocarpus indicus and Pericopsis mooniana in the greenhouse

\begin{tabular}{|c|c|c|c|c|c|}
\hline \multirow{2}{*}{ Plant species treatment } & \multicolumn{5}{|c|}{ Content $\left(\right.$ mg plant $\left.^{-1}\right)$} \\
\hline & $\mathbf{N}$ & $\mathbf{P}$ & $\mathbf{K}$ & Mn & $\mathbf{F e}$ \\
\hline \multicolumn{6}{|l|}{ P. indicus } \\
\hline Control & $43.07 \pm 4.03 b$ & $5.45 \pm 0.63 b$ & $47.85 \pm 2.81 b$ & $0.21 \pm 0.036 b$ & $0.36 \pm 0.101 b$ \\
\hline G. claroideum & $76.03 \pm 7.09 a$ & $7.97 \pm 1.01 b$ & $82.34 \pm 18.03 \mathrm{ab}$ & $0.51 \pm 0.038 \mathrm{a}$ & $0.53 \pm 0.026 b$ \\
\hline G. coronatum & $67.73 \pm 4.52 \mathrm{a}$ & $6.53 \pm 0.59 \mathrm{cb}$ & $61,47 \pm 1.59 \mathrm{ab}$ & $0.46 \pm 0.065 \mathrm{a}$ & $0.51 \pm 0.072 b$ \\
\hline Mixed AMF & $72.05 \pm 6.67 \mathrm{a}$ & $12,50 \pm 1.32 \mathrm{a}$ & $87.84 \pm 11.29 a$ & $0.61 \pm 0.038 \mathrm{a}$ & $2.09 \pm 0.257 \mathrm{a}$ \\
\hline \multicolumn{6}{|l|}{ P. mooniana } \\
\hline Control & $52.32 \pm 1.36 b$ & $8.88 \pm 0.76 b$ & $70.32 \pm 7.03 b$ & $0.40 \pm 0.023 b$ & $0.37 \pm 0.027$ \\
\hline G. claroideum & $177.48 \pm 7.24 \mathrm{a}$ & $24.36 \pm 3.21 \mathrm{a}$ & $210.19 \pm 15.73 a$ & $0.91 \pm 0.077 \mathrm{a}$ & $0.95 \pm 0.097$ \\
\hline G. coronatum & $170.94 \pm 9.81 \mathrm{a}$ & $25.74 \pm 2.44 a$ & $182.16 \pm 13,91 \mathrm{a}$ & $0.86 \pm 0.153 a$ & $1.02 \pm 0.372$ \\
\hline Mixed AMF & $150.87 \pm 21.55 \mathrm{a}$ & $25.04 \pm 3.68 \mathrm{a}$ & $147.66 \pm 36.79 \mathrm{a}$ & $0.96 \pm 0.142 \mathrm{a}$ & $3.76 \pm 0.317$ \\
\hline
\end{tabular}

Note: Average values followed by different letters in the same column are significantly different at LSD (P<0.05); *Mean \pm SE 
Table 8. The effect of AMF inoculation on changes in nutrients contained in the root and shoot of 4-month old $P$. indicus dan $P$. mooniana seedlings in the greenhouse

\begin{tabular}{|c|c|c|c|c|c|c|c|c|c|c|}
\hline \multirow{2}{*}{$\begin{array}{c}\text { Plant species/ } \\
\text { treatment }\end{array}$} & \multicolumn{5}{|c|}{ Roots } & \multicolumn{5}{|c|}{ Shoots } \\
\hline & $\mathbf{N}$ & $\mathbf{P}$ & $\mathbf{K}$ & Mn & $\mathbf{F e}$ & $\mathbf{N}$ & $\mathbf{P}$ & $\mathbf{K}$ & Mn & $\mathbf{F e}$ \\
\hline \multicolumn{11}{|l|}{ P. indicus } \\
\hline G. claroideum & 100.7 & 100.7 & 76.9 & 62.7 & 106.5 & 76.1 & 46.9 & 69.9 & 136.8 & 45.4 \\
\hline G. coronatum & 90.2 & 50.6 & 64.5 & 35.0 & 2.4 & 57.6 & 21.7 & 26.6 & 116.5 & 41.7 \\
\hline Mixed AMF & 72.5 & 59.9 & 75.0 & 60.1 & -55.3 & 30.6 & 89.8 & 12.5 & 42.4 & 72.4 \\
\hline \multicolumn{11}{|l|}{ P. mooniana } \\
\hline G. claroideum & 85.2 & 486.3 & 88.6 & 60.8 & 35.7 & 241.6 & 173.7 & 197.1 & 119.6 & 152.8 \\
\hline G. coronatum & 151.2 & 641.9 & 107.8 & 204.7 & 98.0 & 224.9 & 181.7 & 159.0 & 109.2 & 172.2 \\
\hline Mixed AMF & 46.1 & 242.3 & 30.4 & 41.6 & 11.7 & 140.7 & 90.8 & 54.2 & -11.3 & 43.0 \\
\hline
\end{tabular}

Table 9. Mycorrhizal colonization, shoot height, stem diameter, leaf and leaf dry weight of $P$. indicus and $P$. mooniana grown with or without four-month mycorrhizal fungi colonization in post-gold minefield in Bombana, Southeast Sulawesi, Indonesia

\begin{tabular}{llllll}
\hline $\begin{array}{c}\text { Plant species } \\
\text { treatment }\end{array}$ & $\begin{array}{c}\text { Mycorrhizal } \\
\text { colonization }(\%)\end{array}$ & Shoot height $(\mathbf{c m})^{*}$ & $\begin{array}{c}\text { Stem diameter } \\
(\mathbf{m m}) *\end{array}$ & $\begin{array}{c}\text { Leaf number* } \\
\text { Leaf dry weight } \\
(\mathbf{g}) *\end{array}$ \\
\hline $\boldsymbol{P}$. indicus & & & & & \\
$\quad$ Control & $40.0 \pm 9.01 \mathrm{~b}$ & $125.9 \pm 7.96 \mathrm{c}$ & $16.6 \pm 0.98 \mathrm{~b}$ & $572 \pm 88.86$ & $1.90 \pm 0.36 \mathrm{c}$ \\
G. claroideum & $81.7 \pm 8.90 \mathrm{a}$ & $197.3 \pm 14.9 \mathrm{a}$ & $20.9 \pm 1.01 \mathrm{a}$ & $585 \pm 101.51$ & $6.64 \pm 1.02 \mathrm{ab}$ \\
$\quad \begin{array}{l}\text { G. coronatum } \\
\text { Mixed AMF }\end{array}$ & $84.2 \pm 1.67 \mathrm{a}$ & $162.2 \pm 6.27 \mathrm{~b}$ & $19.5 \pm 0.97 \mathrm{a}$ & $339 \pm 99.24$ & $4.39 \pm 0.75 \mathrm{~b}$ \\
$\boldsymbol{P}$ mooniana & $93.3 \pm 2.20 \mathrm{a}$ & $141.1 \pm 9.33 \mathrm{bc}$ & $18.8 \pm 1.53 \mathrm{ab}$ & $829 \pm 42.00$ & $8.15 \pm 0.34 \mathrm{a}$ \\
$\quad$ & & & & \\
$\quad$ Control & $7.5 \pm 3.82 \mathrm{~b}$ & $5.3 \pm 0.69 \mathrm{c}$ & $1.78 \pm 0.25 \mathrm{c}$ & $31 \pm 5.86 \mathrm{~d}$ & $0.65 \pm 0.16 \mathrm{~b}$ \\
G. claroideum & $18.3 \pm 4.64 \mathrm{~b}$ & $7.6 \pm 0.35 \mathrm{c}$ & $2.65 \pm 0.45 \mathrm{c}$ & $82 \pm 2.02 \mathrm{~b}$ & $0.75 \pm 0.01 \mathrm{~b}$ \\
$\quad \begin{array}{l}\text { G. coronatum } \\
\text { Mixed AMF }\end{array}$ & $50.0 \pm 10.90 \mathrm{a}$ & $39.1 \pm 1.73 \mathrm{a}$ & $6.37 \pm 0.10 \mathrm{a}$ & $105 \pm 3.46 \mathrm{a}$ & $1.48 \pm 0.28 \mathrm{a}$ \\
\hline
\end{tabular}

Note: Average values followed by different letters in the same column are significantly different at LSD (P<0.05); *Mean \pm SE

\section{Mycorrhizal colonization and plant growth in the post- gold minefield}

The number of colonization of $G$. claroideum, $G$. coronatum and mixed AMF on $P$. indicus roots was higher than on $P$. mooniana roots at 4 months after planting in the post-gold minefield (Table 9). There was no significant difference in the percentage of colonization between $G$. claroideum, G. coronatum and mixed AMF on $P$. indicus. Seedlings in control treatment of $P$. indicus and $P$. mooniana were colonized by indigenous AM Fungi.

Colonization by the Arbuscular mycorrhizal fungi G. claroideum and G. coronatum increased shoot height and stem diameter of $P$. indicus (Table 9). However, colonization by mixed AMF did not increase shoot height and stem diameter of $P$. indicus. There was no significant difference in number of leaves on $P$. indicus seedlings colonized by AMF and control. Leaf dry weight of $P$. indicus colonized by AMF was higher than control.

Shoot height, stem diameter, and leaf dry weight of $P$. mooniana colonized by $G$. coronatum and mixed AMF was higher than that of control and G. claroideum colonization (Table 9). There was no significant difference in shoot height, stem diameter and leaf dry weight of seedling colonized by $G$. claroideum and control. Seedlings colonized by $G$. coronarum had higher number of leaf and leaf dry weight than seedlings in control treatment.

Pterocarpus indicus and P. moniana can adapt and grow on tailing soil media and post-gold post minefield with a seedling survival rate of $100 \%$. These species are potential to be used as tree species for revegetation of postgold mining land in the tropics. $P$. indicus can be grown in open land due to its light-demanding species, grows in various soil conditions and fast-growing species. Meanwhile, $P$. mooniana can be grown with enrichment planting technique because it requires shade at the beginning of its growth. Both species are suitable to be developed as revegetation species because they meet the requirements of economic importance, $\mathrm{N}$-fixing capacity, fast-growing, tolerance to adverse climate and soil conditions, have a deep root system and are easy to propagate (Maiti 2013). The results of this study indicate that post-mining land can be used as an ex-situ conservation area for endangered tree species. Therefore, mining reclamation policies in tropics should oblige mining companies to use tropical tree species as one of the selected species for post-mining land reclamation.

Based on the results of this study, indicated that AMF has a very important role in ecological restoration and conservation of endangered tropical tree species. It is due to the ability of AMF to increase the surface area of root absorption by 100 or even 1000 times (Larcher 1995). Therefore, it can improve plant nutrient status and water status (Smith and Read 2008). AMF can also improve soil structure and plant resistance to environmental stress and reduce the need for fertilizer use. 
Table 10. Shoot N, P, K, Mn and Fe content of Pterocarpus indicus and Pericopsis mooniana grown with or without four-month mycorrhizal fungi inoculation in post gold minefield in Bombana, Southeast Sulawesi, Indonesia

\begin{tabular}{|c|c|c|c|c|c|}
\hline \multirow{2}{*}{ Plant species treatment } & \multicolumn{5}{|c|}{ Concentration $\left(\mathrm{mg} \mathrm{g}^{-1}\right)$} \\
\hline & $\mathbf{N}$ & $\mathbf{P}$ & $\mathbf{K}$ & Mn & $\mathbf{F e}$ \\
\hline \multicolumn{6}{|l|}{ P. indicus } \\
\hline Control & $38.7 \pm 0.17$ & $2.6 \pm 0.01$ & $16.4 \pm 0.27$ & $0.47 \pm 0.123$ & $0.25 \pm 0.041$ \\
\hline G. claroideum & $41.1 \pm 0.33$ & $3.3 \pm 0.01$ & $23.5 \pm 0.26$ & $0.39 \pm 0.103$ & $0.27 \pm 0.046$ \\
\hline G. coronatum & $38.7 \pm 0.29$ & $2.9 \pm 0.04$ & $25.3 \pm 0.14$ & $0.13 \pm 0.043$ & $0.20 \pm 0.003$ \\
\hline Mixed AMF & $39.2 \pm 0,33$ & $2.8 \pm 0.01$ & $20.2 \pm 0.16$ & $0.25 \pm 0.039$ & $0.23 \pm 0.019$ \\
\hline \multicolumn{6}{|l|}{ P. mooniana } \\
\hline Control & $14.3 \pm 0.78$ & $1.3 \pm 0.07$ & \multirow{3}{*}{$\begin{array}{l}7.9 \pm 0.45 \\
13.4 \pm 0.17 \\
14.8 \pm 0.16\end{array}$} & $0.044 \pm 0.028$ & $0.12 \pm 0.060$ \\
\hline \multirow{2}{*}{$\begin{array}{l}\text { G. claroideum } \\
\text { G. coronatum }\end{array}$} & $28.0 \pm 0.27$ & $2.2 \pm 0.04$ & & $0.085 \pm 0.024$ & $0.15 \pm 0.039$ \\
\hline & $29.1 \pm 0.54$ & $2.0 \pm 0.01$ & & $0.139 \pm 0.056$ & $0.18 \pm 0.038$ \\
\hline Mixed AMF & $24.6 \pm 0.20$ & $1.7 \pm 0.01$ & $11.3 \pm 0.15$ & $0.084 \pm 0.011$ & $0.14 \pm 0.027$ \\
\hline
\end{tabular}

Table 11. Shoot N, P, K, Mn, and Fe contents of Pterocarpus indicus and Pericopsis mooniana grown with or without mycorrhizal fungi under post gold mining land conditions in Bombana, Southeast Sulawesi, Indonesia, for four months

\begin{tabular}{|c|c|c|c|c|c|}
\hline \multirow[t]{2}{*}{ Plant species treatment } & \multicolumn{5}{|c|}{ Content $\left(\text { mg plant }^{-1}\right)^{*}$} \\
\hline & $\mathbf{N}$ & $\mathbf{P}$ & $\mathbf{K}$ & Mn & $\mathbf{F e}$ \\
\hline \multicolumn{6}{|l|}{ P. indicus } \\
\hline Control & $73.53 \pm 14.4 \mathrm{c}$ & $4.94 \pm 0.1 \mathrm{c}$ & $31.16 \pm 2.4 \mathrm{~b}$ & $0.89 \pm 0.33$ & $0.48 \pm 0.160 \mathrm{~b}$ \\
\hline G. claroideum & $272.90 \pm 59.1 \mathrm{ab}$ & $21.91 \pm 03.5 \mathrm{a}$ & $156.04 \pm 29.8 \mathrm{a}$ & $2.59 \pm 0.99$ & $1.79 \pm 0.460 \mathrm{a}$ \\
\hline G. coronatum & $169.89 \pm 29.2 \mathrm{bc}$ & $12.73 \pm 0.4 \mathrm{~b}$ & $111.07 \pm 12.6 \mathrm{a}$ & $0.57 \pm 0.003$ & $0.88 \pm 0.154 \mathrm{ab}$ \\
\hline Mixed AMF & $319.48 \pm 1.53 \mathrm{a}$ & $22.82 \pm 0.9 \mathrm{a}$ & $164.63 \pm 12.0 \mathrm{a}$ & $2.04 \pm 0.76$ & $1.87 \pm 0.248 \mathrm{a}$ \\
\hline \multicolumn{6}{|l|}{ P. mooniana } \\
\hline Control & $9.30 \pm 4.5 \mathrm{c}$ & $0.85 \pm 0.4 \mathrm{~b}$ & $5.14 \pm 2.3 \mathrm{~b}$ & $0.03 \pm 0.03 \mathrm{~b}$ & $0.08 \pm 0.050 \mathrm{~b}$ \\
\hline G. claroideum & $21.00 \pm 2.4 \mathrm{c}$ & $1.65 \pm 0.2 \mathrm{~b}$ & $10.05 \pm 1.4 \mathrm{~b}$ & $0.06 \pm 0.01 \mathrm{~b}$ & $0.11 \pm 0.011 \mathrm{~b}$ \\
\hline G. coronatum & $43.07 \pm 4.8 \mathrm{a}$ & $2.96 \pm 0.5 \mathrm{a}$ & $21.90 \pm 5.7 \mathrm{a}$ & $0.21 \pm 0.001 \mathrm{a}$ & $0.276 \pm 0.04 \mathrm{a}$ \\
\hline Mixed AMF & $27.31 \pm 4.2 \mathrm{~b}$ & $1.89 \pm 0.7 \mathrm{ab}$ & $12.54 \pm 5.2 \mathrm{ab}$ & $0.09 \pm 0.002 \mathrm{~b}$ & $0.16 \pm 0.033 \mathrm{~b}$ \\
\hline
\end{tabular}

Note: Average values followed by different letters in the same column are significantly different at LSD (P<0.05); *Mean \pm SE

\section{Shoot N, P, K, Mn and Fe contents in the post-gold minefield}

There was no difference in shoot N, P, K, Mn and Fe concentration of $P$. mooniana and $P$. indicus among the inoculated seedlings (Table 10). AMF inoculation by $G$. claroideum, $G$. coronatum and mixed AMF increased shoot $\mathrm{N}, \mathrm{K}$ and $\mathrm{Mn}$ content of $P$. indicus, but there was no significant difference in shoot $\mathrm{K}$ content of $P$. indicus seedlings inoculated G. claroideum, G. coronatum and control. $P$. indicus colonized by mixed AMF had higher shoot $\mathrm{P}$ and $\mathrm{Fe}$ content than control and $G$. coronatum colonization (Table 11). AMF inoculation by $G$. claroideum, G. coronatum, and mixed AMF increased shoot N, P, K and Mn content of P. mooniana. Shoot Fe content of $P$. mooniana was not significantly different among the seedlings.

Our results also showed the increase of shoots and roots $\mathrm{N}, \mathrm{P}, \mathrm{K}$ content of $P$. indicus and $P$. mooniana by AMF colonization in four-month-old in the greenhouse. AMF fungal inoculation improved shoot $\mathrm{N}, \mathrm{P}$ and $\mathrm{K}$ uptake of $P$. indicus and $P$. mooniana in post-gold minefield. N, P and $\mathrm{K}$ are macronutrients that are essential for plant growth and development. Our results are in line with previous studies showing that AMF can increase $\mathrm{N}$ and $\mathrm{P}$ uptake in $P$. mooniana (Husna et al. 2015; 2016; 2019a) and K. celebica (Husna et al. 2021). Increased nutrient uptake by AMF in low fertility soils indicates that AMF can reduce fertilizer use. However, the applications of organic and inorganic fertilizers are strongly needed for planting activities on post-gold mining land (Muddarisna and Siahaan 2014; Sulakhudin et al. 2017).

Mixed AMF decreased Fe content in the roots of $P$. indicus and $\mathrm{Mn}$ content in the shoots of $P$. mooniana (Table 4) in plant grown in the greenhouse. Inoculation of $G$. coronatum decreased $\mathrm{Mn}$ content in the shoots of $P$. indicus. In gold tailings soil media, the application of mixed AMF also reduced Fe content by $15 \%$ in the roots of K. celebica (Husna et al. 2021), while Glomus sp. reduced Fe content by $13 \%$ in the roots of $N$. orientalis (Tuheteru et al. 2017).

In conclusion, the results of our study in the greenhouse and post-gold mining field demonstrated that AMF promoted growth and increased nutrient uptake of $P$. indicus and $P$. mooniana seedlings four months after planting. AMF has the potential to be developed as a biofertilizer in the cultivation of $P$. indicus and $P$. mooniana and the conservation of endangered tropical trees in the tropics and may be adopted in large scale nurseries along with reforestation. 


\section{ACKNOWLEDGEMENTS}

The authors would like to thank the Ministry of Research and Technology/BRIN of the Republic of Indonesia for the financial support. The authors also thank the Chairman of PT. Panca Logam Makmur for providing research site and Prof. Keitaro Tawaraya (Yamagata University, Japan) for proofreading.

\section{REFERENCES}

Agus C, Primananda E, Faridah E, Wulandari D, Lestari T. 2018. Role of arbuscular mycorrhizal fungi and Pongamia pinnata for revegetation of tropical open-pit coal mining soils. Intl J Environ Sci Technol 16: 3365-3374. DOI: 10.1007/s13762-018-1983-5.

Amir H, Cavaloc Y, Laurent A, Pagand P, Gunkel P, Lemestre M, Médevielle V, Pain A, McCoy S. 2019. Arbuscular mycorrhizal fungi and sewage sludge enhance growth and adaptation of Metrosideros laurifolia on ultramafic soil in New Caledonia: A field experiment. Sci. Total Environ 651: 334-343. DOI 10.1016/j.scitotenv.2018.09.153.

Asmelash F, Bekele T, Birhane E. 2016. The potential role of arbuscular mycorrhizal fungi in the restoration of degraded lands. Front Microbiol 7: 1095. DOI: 10.3389/fmicb.2016.01095.

Balai Penelitian Tanah. 2009. Petunjuk Teknis Analisis Tanah, Tanaman, Air dan Pupuk. Balai Penelitian Tanah, Bogor. [Indonesian]

Bothe H, Turnau K, Regvar M. 2010. The potential role of arbuscular mycorrhizal fungi in protecting endangered plants and habitats [review]. Mycorrhiza 20: 445-457. DOI: 10.1007/s00572-010-0332-4

Brundrett M, Bougher N, Dell B, Grove T, Majalaczuk. 1996. Working with mycorrhizas in forestry and agriculture. Australian Centre for International Agriculture Research, Canberra.

Carter MR. 1993. Soil sampling and methods of analysis Boca Raton. Lewis Publishers, USA.

Dhalaria R, Kumar D, Kumar H, Nepovimova E, Ku`ca K, Islam MT, Verma R. 2020. Arbuscular mycorrhizal fungi as potential agents in ameliorating heavy metal stress in plants. Agronomy 10 (6): 815 . DOI: 10.3390/agronomy10060815.

Duryea ML, Brown GN. 1984. Seedling physiology and reforestation success. Proceeding of the physiology working group Technical Session. Dr. W. Juck Publishers, Boston. DOI: 10.1007/978-94-009 6137-1.

FAO, UNEP. 2020. The State of the World's Forests 2020. Forests, biodiversity and people. FAO, Rome. DOI: 10.4060/ca8642en.

Fiqri A, Utomo WH, Handayanto E. 2016. Effect of arbuscular mycorrhizal fungi on the potential of three wild plant species for phytoextraction of mercury from small-scale gold mine tailings. J. Degrade. Min. Land Manag 3 (3): 551-558. DOI: 10.15243/jdmlm.2016.033.551.

Fuchs B, Haselwandter K. 2008. Arbuscular mycorrhiza of endangered plant species: potential impacts on restoration strategies. In: Varma A (eds.) Mycorrhiza. Springer, New York. DOI: 10.1007/978-3-540-78826-3_27.

Gazal RM, Blanche CA, Carandang WM. 2004. Root growth potential and seedling morphological attributes of narra (Pterocarpus indicus Willd.) transplants. For Ecol Manag 195: 259-266. DOI: 10.1016/j.foreco.2004.03.023.

Giri B, Kapoor R, Mukerji K. 2005. Effect of the arbuscular mycorrhizae Glomus fasciculatum and G. macrocarpum on the growth and nutrient content of Cassia siamea in a semi-arid Indian wasteland soil. New For 29: 63-73. DOI: 10.1007/s11056-004-46890 .

Habte M, Manjunath A. 1991. Categories of vesicular-arbuscular mycorrhizal dependency of host species. Mycorrhiza 1: 3-12. DOI: $10.1007 / \mathrm{BF} 00205896$

Husna, Budi SWR, Mansur I, Kusmana C. 2015b. Diversity of arbuscular mycorrhizal fungi in the growth habitat of kayu kuku (Pericopsis mooniana Thw.) in South East Sulawesi). Pak J Biol Sci 18 (1): 1-10. DOI: 10.3923/pjbs.2015.1.10.

Husna, Budi SWR, Mansur I, Kusmana C. 2016. Growth and nutrient status of Kayu Kuku (Pericopsis mooniana Thw.) with mycorrhiza in soil media of nickel post mining. Pak J Biol Sci 19: 158-170. DOI: 10.3923/pjbs.2016.158.170

Husna, Mansur I, Budi SWR, Tuheteru FD, Arif A, Tuheteru EJ, Albasri. 2019a. Effects of arbuscular mycorrhizal fungi and organic material on growth and nutrient uptake by Pericopsis mooniana in coal mine. Asian J Plant Sci 18: 101-109. DOI: 10.3923/ajps.2019.101.109.

Husna, Tuheteru FD, Arif A. 2017. Arbuscular mycorrhizal fungi and plant growth on serpentine soils. In: Wu QS (eds.) Arbuscular mycorrhizas and stress tolerance of plants. Springer, Singapore. DOI: 10.1007/978-981-10-4115-0_12.

Husna, Tuheteru FD, Arif A. 2021. The potential of arbuscular mycorrhizal fungi to conserve Kalappia celebica, an endangered endemic legume on gold mine tailings in Sulawesi, Indonesia. J For Res 32: 675-682. DOI: 10.1007/s11676-020-01097-8.

Husna, Tuheteru FD, Arif A, Solomon. 2019b. Improvement of early growth of endemic Sulawesi trees species Kalappia celebica by arbuscular mycorrhizal fungi in gold mining tailings. IOP Conf Ser: Earth Environ Sci 394: 012069. DOI: 10.1088/17551315/394/1/012069.

Husna, Tuheteru FD, Arif A. 2018. Arbuscular mycorrhizal fungi symbiosis and conservation of endangered tropical legume trees. In: Giri B et al. (eds) Root Biology, Soil Biology 52. Springer, Germany. DOI: 10.1007/978-3-319-75910-4_19.

Husna, Budi RSW, Mansur I, Kusmana C. 2015a. Respon pertumbuhan bibit kayu kuku (Pericopsis mooniana (Thw.) Thw.) terhadap inokulasi fungi mikoriza arbuskula lokal. Pemuliaan Tanaman Hutan 9 (3): 131-148. DOI: 10.20886/jpth.2015.3.131-148 [Indonesian]

[IUCN] International Union for Conservation of Nature and Natural Resources. 2014. IUCN Red List of Threatened Species. Version 2014.2.3.

Larcher W. 1995. Physiological Plant Ecology. Springer-Verlag, Berlin. DOI: $10.1007 / 978-3-642-87851-0$.

Madejón E, Doronila AI, Madejón P, Baker AJ, Woodrow IE. 2012. Biosolids, mycorrhizal fungi and eucalypts for phytostabilization of arsenical sulphidic mine tailings. Agrofor Syst 84 (3): 389-399. DOI: 10.1007/s10457-012-9484-x.

Maiti SK. 2013. Ecorestoration of the coalmine degraded lands. Springer, India. DOI: 10.1007/978-81-322-0851-8_11

Manipol MM, Tinio CE, Maldia LS, Combalicer MS. 2020. Salinityinduced changes in the morphology, physiology, and anatomy of seeds and seedlings of smooth narra (Pterocarpus indicus Willd. f. indicus). Biodiversitas 21 (11): 5146-5154. DOI: 10.13057/biodiv/d211120.

Maulana AF, Turjaman M, Sato T, Hashimoto Y, Cheng W, Tawaraya K. 2017. Growth response of four leguminous trees to native arbuscular mycorrhizal fungi from tropical forest in Indonesia. Intl J Plant Soil Sci 20 (3): 1-13. DOI: 10.9734/IJPSS/2017/37433.

Muddarisna N, Siahaan BC. 2014. Application of organic matter to enhance phytoremediation of mercury-contaminated soils using local plant species: a case study on small-scale gold mining locations in Banyuwangi of East Java. J Degraded Mining Land Manag 2 (1): 251-258.

Muin A. 2003. Pertumbuhan anakan Ramin (Gonystylus bancanus (Miq.) Kurz)) dengan inokulasi cendawan mikoriza arbuskula (CMA) pada berbagai intensitas cahaya dan dosis fosfat alam. [Dissertation]. Program Pascasarjana, Institut Pertanian Bogor, Bogor. [Indonesian]

Orłowska ED, Orłowski J, Mesjasz-Przybyłowicz, Turnau K. 2011. Role of mycorrhizal colonization in plant establishment on an alkaline gold mine tailing. Intl J Phytoremediation 13: 185-205. DOI: 10.1080/15226514.2010.495148.

Panwar J, Tarafdar JC. 2006. Distribution of three endangered medicinal plant species and their colonization with arbuscular mycorrhizal fungi. $J$ Arid Environ 65: 337-350. DOI: 10.1016/j.jaridenv.2005.07.008.

Prematuri R, M. Turjaman, K Tawaraya. 2020. Effect of arbuscular mycorrhiza fungal inoculation on growth of tropical tree species under nursery and post-opencast bauxite mining field in Bintan Island, Indonesia. Intl J Plant Soil Sci 32 (20): 1-13. DOI: 10.9734/ijpss/2020/v32i2030397.

Riaz M, Kamran M, Fang Y, Wang Q, Cao H, Yang G, Deng L, Wang Y, Zhou Y, Anastopoulos I, Wang. 2021. Arbuscular mycorrhizal fungiinduced mitigation of heavy metal phytotoxicity in metal contaminated soils: A critical review. J Hazard Mater 402: 123919. DOI: $10.1016 /$ j.jhazmat.2020.123919. 
Sheoran V, Sheoran AS, Poonia R. 2010. Soil reclamation of abandoned mine land by revegetation: a review. Intl J Soil Sediment Water 3: 120.

Smith SE, Read DJ. 2008. Mycorrhizal symbiosis. Third ed. Academic Press USA.

Soerianegara I, Lemmens RHMJ. 1994. Plant Resources of South-East Asia No 5(1) Timber Trees: Major Commercial Timbers. Prosea Foundation, Bogor. [Indonesian]

Sulakhudin, Suswati D, Hatta M. 2017. The effect of ameliorants on improvement of soil fertility in post gold mining land at Wes Kalimantan. J Degraded Mining Land Manag 4 (4): 873-880. DOI: 10.15243/jdmlm.2017.044.873.

Thomas E, Jalonen R, Loo J, Boshier D, Gallo L, Cavers S, Bordács S, Smith P, Bozzano M. 2014. Genetic considerations in ecosystem restoration using native tree species. For Ecol Manag 333: 66-75. DOI: 10.1016/j.foreco.2014.07.015.

Thomson LAJ. 2006. Pterocarpus indicus (narra). In: Elevitch CR (ed) Species profiles for Pacific Island agroforestry. ver. 2.1. Permanent Agriculture Resources (PAR), Hōlualoa. http://www.traditionaltree.org.

Tuheteru FD, Kusmana C, Mansur I, Iskandar, Tuheteru EJ. 2016 Potential of lonkida (Nauclea orientalis L.) for phytoremediation of acid mined drainage at PT. Bukit Asam Tbk. (Persero), Indonesia. Res J Bot 11: 9-17. DOI: 10.3923/rjb.2016.9.17.

Tuheteru FD, Asrianti A, Widiastuti E, Rahmawati N. 2017. Heavy metal uptake by indigenous arbuscular mycorrhizas of Nauclea orientalis L. and the potential for phytoremediation of serpentine soil. J For Sci 11 (1): 76-84. DOI: $10.22146 /$ jik.24902.

Tuheteru FD, QS Wu. 2017. Arbuscular Mycorrhizal Fungi and Tolerance of Waterlogging Stress in Plants. In: Wu QS (ed.) Arbuscular Mycorrhizas and Stress Tolerance of Plants. Springer, Singapore. DOI: 10.1007/978-981-10-4115-0_3.

Tuheteru FD, Arif A, Wulan SA, Kramadibrata K. 2019. Arbuscular mycorrhizal fungi associated with adaptive plants in gold mine tailing. Biodiversitas 20 (11): 3398-3404. DOI 10.13057/biodiv/d201137.

Tuheteru FD, Arif A, Husna, Mansur I, Tuheteru EJ, Jusniar, Basrudin, Albasri, Hadijah MH, Karepesina S. 2020. Arbuscular mycorrhizal fungal inoculation improves Nauclea orientalis L. growth and phosphorus uptake in gold mine tailing soil media. J Degraded Mining Land Manag 7 (3): 2193-2200. DOI: 10.15243/jdmlm.2020.073.2193.
Turjaman M, Santosa E, Sumarna Y. 2006a. Arbuscular mycorrhizal fungi increased early growth of gaharu wood species Aquilaria malaccensis and A. crasna under greenhouse conditions. J For Res 3 (2): 139-148. DOI: 10.20886/ijfr.2006.3.2.139-148.

Turjaman M, Tamai Y, Santoso E, Osaki M, Tawaraya K. 2006b. Arbuscular mycorrhizal fungi increased early growth of two nontimber forest product species Dyera polyphylla and Aquilaria filaria under greenhouse conditions. Mycorrhiza 16: 459-464. DOI: 10.1007/s00572-006-0059-4.

Turjaman M, Santoso E, Tawaraya K. 2007. Arbuscular mycorrhizal fungi increased plant growth and nutrient concentrations of milkwood tropical tree species Alstonia scholaris under greenhouse conditions. J For Res 4 (2): 61-71. DOI: 10.20886/ijfr.2007.4.2.61-71.

Turjaman M, Santoso E, Sitepu IR, Tawaraya K, Purnomo E, Tambunan R, Osaki M. 2009. Mycorrhizal fungi increased early growth of tropical tree seedlings in adverse soil. J For Res 6 (1): 17-25. DOI: 10.20886/ijfr.2009.6.1.17-25.

Urgiles N, Loja'n P, Aguirre N, Blaschke H, Gu"nter S, Stimm B , Kottke, I. 2009. Application of mycorrhizal roots improves growth of tropical tree seedlings in the nursery: a step towards reforestation with native species in the Andes of Ecuador. New For 38: 229-239. DOI: $10.1007 / \mathrm{s} 11056-009-9143-\mathrm{x}$

Wang F, Lin X, Yin R. 2005. Heavy metal uptake by arbuscular mycorrhizas of Elsholtzia splendens and the potential for phytoremediation of contaminated soil. Plant Soil 269: 225-223. DOI: $10.1007 / \mathrm{s} 11104-004-0517-8$

Wang F. 2017. Arbuscular mycorrhizas and ecosystem restoration. In: QS Wu (eds) Arbuscular mycorrhizas and stress tolerance of plants. Springer, Singapore. DOI: 10.1007/978-981-10-4115-0_11.

Wulandari D, Saridi, Cheng W, Tawaraya K. 2016. Arbuscular mycorrhizal fungal inoculation improves Albizia saman and Paraserianthes falcataria growth in post-opencast coal minefield in East Kalimantan, Indonesia. For Ecol Manag 376: 67-73. DOI: 10.1016/j.foreco.2016.06.008

Wulandari D, Saridi, Cheng W, Tawaraya K. 2014. Arbuscular mycorrhizal colonization enhanced early growth of Mallotus paniculatus and Albizia saman under nursery conditions in East Kalimantan, Indonesia. Intl J For Res 2014:898494. DOI: $10.1155 / 2014 / 898494$.

Zubek S, Turnau K, Tsimilli-Michael M, Strasser RJ. 2009. Response of endangered plant species to inoculation with arbuscular mycorrhizal fungi and soil bacteria. Mycorrhiza 19: 113-123. DOI: 10.1007/s00572-008-0209-y. 